\title{
A case of delayed carotid cavernous fistula after facial gunshot injury presented as loss of vision with symptom resolution after endovascular closure procedure
}

\author{
Fatih Alagöz, M.D.,, Fevzi Yılmaz, M.D., ${ }^{2}$ Bedriye Müge Sönmez, M.D., ${ }^{2}$ \\ Ali Erdem Yıldırım, M.D., ${ }^{1}$ Muhammed Evvah Karakılıç, M.D. ${ }^{2}$ \\ 1'Department of Neurosurgery, Ankara Numune Training and Research Hospital, Ankara-Turkey \\ ${ }^{2}$ Department of Emergency Medicine, Ankara Numune Training and Research Hospital, Ankara-Turkey
}

\begin{abstract}
Carotid cavernous fistulas (CCFs) are abnormal connections between the carotid artery and the cavernous sinus (CS), and can occur as a result of blunt and penetrating head injuries. While occurrence is rare, diagnosis can be made in the emergency department. Described in the present report is the case of a 26-year-old man who presented with complaints of pain, redness, blurred and loss of vision in the right eye, and swelling of the upper face due to a gunshot injury he had sustained 35 days prior.
\end{abstract}

Keywords: Carotid cavernous fistula; endovascular intervention; endovascular treatment; gunshot injury.

\section{INTRODUCTION}

Post-traumatic carotid cavernous fistulas (CCFs) are direct communications between the internal carotid artery (ICA) and the cavernous sinus (CS), frequently encountered as a complication of closed head trauma, though occurrence has been reported in relation to penetrating object or gunshot injury. ${ }^{[l]}$ CCFs tend to be diagnosed a few weeks after trauma, and the majority of signs and symptoms result from increased venous pressure in an ophthalmic vein that lacks a valve. ${ }^{[2]}$ While CCFs are not life-threatening, timing of diagnosis is extremely important, as permanent loss of vision may develop within hours or days of initial injury. The most common signs and symptoms are pulsatile exophthalmus, orbital murmur, conjunctival hyposphagma, ophthalmoplegia, orbital pain, and impaired visual acuity. ${ }^{[1,3]}$

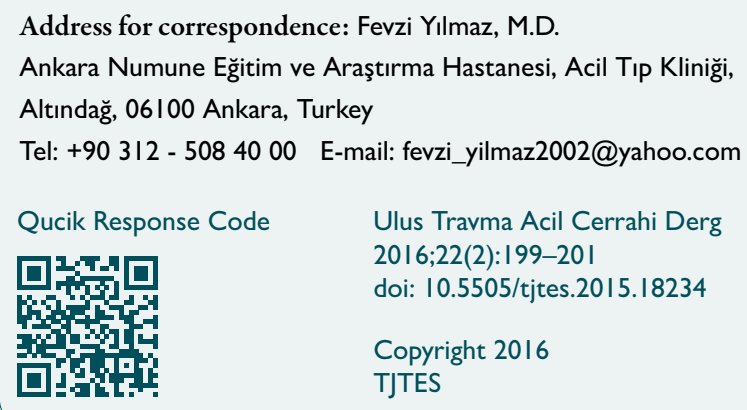

Computed tomography angiography with pathognomonic radiological signs can aid diagnosis and may be used for screening. Precise location of the fistula and nature of the lesion can be studied further with digital subtraction angiography. ${ }^{[4]}$

Endovascular embolization has been the preferred treatment approach throughout the past 2 decades, and surgical treatment remains an option when endovascular treatment fails or is not possible. ${ }^{[5,6]}$ Discussed in the present report is the presentation, pathogenesis, and management of carotid CS fistulas.

\section{CASE REPORT}

A 26-year-old man presented to emergency services with pain, redness, and blurred and loss of vision in the right eye. Initial complaints were mild and first noted 15 days prior to clinical presentation. History was unremarkable with the exception of a gunshot injury to the face sustained 35 days prior, which had been managed through conservative measures.

On physical examination, general status was normal, and scar tissue was noted over the right nasal sulcus, indicating bullet entry. Neurological examination revealed no abnormality. Typical murmur was audible at the right orbit, suggesting diagnosis of CCF. Initial radiographic scans revealed a bullet in the right side of the face (Fig. I). The patient was referred to ophthalmology, and upon examination, corrected visual acuity 
was 0.3 on the right side and $\mathrm{I} .0$ on the left. Biomicroscopic evaluation was compatible with eyelid edema, chemosis, proptosis, dilated fixed pupils, and negative light reflex in the right eye. Fundoscopic examination revealed marked venous congestion and increased tortuosity, arteriolar thinning, and preretinal hemorrhages in the right eye. Intraocular pressure measured with tonometry was $34 \mathrm{mmHg}$ in the right eye and $16 \mathrm{mmHg}$ in the left.

Color Doppler ultrasonography, orbital tomography with and without contrast on the axial plane, magnetic resonance imaging, magnetic resonance angiography, and digital subtraction angiography confirmed diagnosis of CCF. Examinations revealed fistula between the right ICA and right CS (Fig. 2a). Endovascular treatment was performed via femoral artery access under general anesthesia without complication. Postoperative course was uneventful, and typical murmurs disappeared on auscultation of the orbit. Complaints of pain, redness, and blurred and loss of vision in the right eye markedly improved within 3 weeks of intervention. Postoperative angiographic scans demonstrated complete obliteration of the fistula (Fig. 2b).

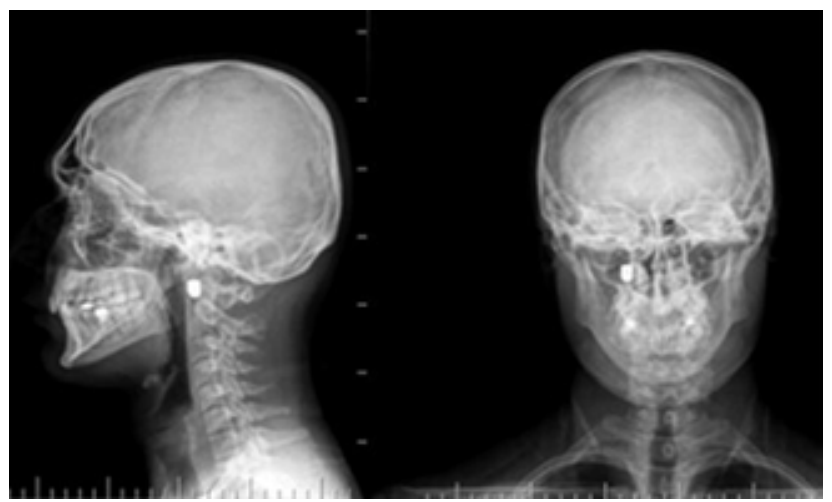

Figure 1. AP and lateral X-ray of the head reveal a bullet in the right side, in front of the $\mathrm{C} 1$ vertebra.

(a)

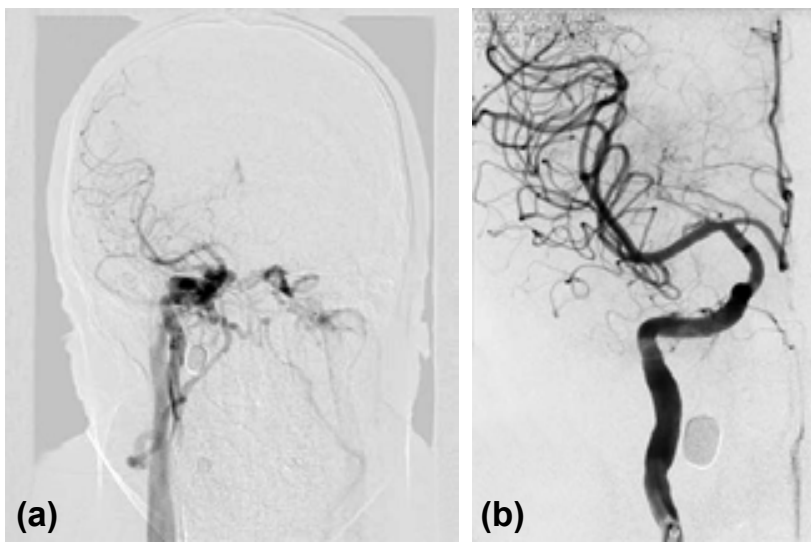

Figure 2. (a) AP digital subtraction angiography shows high-output arteriovenous fistula at the cavernous segment of the right ICA. (b) Fistula appears occluded, and filling pattern of distal segments of the right middle cerebral artery and anterior cerebral artery appear markedly improved on AP angiographic examination following stent-graft procedure.

\section{DISCUSSION}

CCFs are identified as direct and abnormal communication between the CS and the ICA, one of its branches, or the external carotid artery. ${ }^{[7]}$ CCFs are rare complications of head trauma, with reported incidence around $0.2-0.3 \%{ }^{[3]}$ Several classifications based on angiographic features (high-flow vs low-flow fistulas), mechanism of onset (spontaneous vs traumatic), morphological features, and angioarchitecture (direct vs indirect fistulas) have been suggested. ${ }^{[8]}$

Drainage pattern and instant development of fistula are typically associated with the signs and symptoms. As a rule of thumb, direct fistulas usually exhibit more dramatic clinical presentation, not infrequently displaying the so-called "classical" triad of exophthalmus, chemosis, and loss of vision. A study of direct CCFs in a large patient series demonstrated that the most common symptoms at initial presentation were orbital bruit $(80 \%)$, proptosis $(72 \%)$, chemosis $(55 \%)$, cranial nerve VI palsy (49\%), complete ophthalmoplegia (24\%), and loss of vision (18\%). ${ }^{[6,9]}$ In agreement with the literature, many of these clinical findings were observed in the present case.

CCFs may go undiagnosed after major craniofacial trauma, and eyelid auscultation for potential murmur is an appropriate clinical approach. CCFs are commonly accompanied by diplopia due to etiology of ischemic or compressive mechanical cranial neuropathy, as well as restricted orbital motion inside the eye socket secondary to venous hypertension. ${ }^{[10]}$ Both direct and indirect fistulas with retrograde cortical venous drainage could lead to intracranial bleeding. The latter is a particularly ominous occurrence, with a high rate of rebleeding over a short time in cases of direct CCF. Therefore, appropriate therapy should be initiated at once if such a devastating complication occurs. ${ }^{[1]}$

Computed tomography and magnetic resonance imaging may reveal indirect signs of these fistulas, including engorgement of the CS region or abnormally dilated venous segments. Nevertheless, conventional transluminal angiography remains the gold standard for both detection and typing of CCFs. Complete and technically correct cerebellar angiography should provide information regarding internal and external carotid supply, and delineate contralateral side and posterior circulation. ${ }^{[12,13]}$

In instances of traumatic fistula, intervention is required in urgent conditions such as progressive loss of vision, intolerable murmur, and headache, as well as in cases of traumatic aneurysm showing signs of dilatation behind the CS, hemiplegia secondary to intracranial hematoma, impairment of cortical venous drainage, severe epistaxis, or intraocular pressure exceeding $40 \mathrm{mmHg}$. Dural sinus fistulas may spontaneously regress in $20-50 \%$ of cases. In cases not requiring urgent intervention, carotid jugular compression may be another palliative treatment option. ${ }^{[14]}$ 
Modalities described for the treatment of CCFs vary from conservative management, surgical management, stereotactic radiosurgery, and endovascular repair through arterial or venous access. Treatment modality is selected according to type and exact anatomy of the fistula, size of the arterial defect, and operator/institutional preferences. ${ }^{[15,16]}$

In cases of traumatic CCFs, embolization of the fistula by transarterial placement of detachable balloons, platinum coils, polyvinyl alcohol particulates, and liquid embolic agents has become preferred procedure, while combined approaches including stenting, either alone or with coil placement, can also be used. ${ }^{[17,18]}$ While transvenous embolization is the preferred approach in cases of indirect CCF, it also serves as an alternative approach when arterial route has failed in cases of direct CCF. ${ }^{[19]}$ Possible complications of arterial approach include cerebral ischemia or infarction due to displacement of embolic material, and arterial dissection or formation of pseudoaneurysm due to arterial wall injury. ${ }^{[6]}$

Surgical treatment of CCFs must be limited to cases in which endovascular treatment fails or is not possible. Techniques may include the placement of packing inside the CS to occlude the fistula, suturing or clipping the fistula, sealing the fistula with fascia and glue, and/or ligation of the ICA. ${ }^{[18]}$

Described in the present report was a case of traumatic carotid CS fistula successfully treated with advanced radiological techniques and interventions in a short period of time. The potential for occurrence of CCF should be kept in mind following facial gunshot injuries, in an effort to avoid ocular and cerebral complications.

Conflict of interest: None declared.

\section{REFERENCES}

1. Wallick K $4^{\text {th }}$, Davidson P, Shockley L. Traumatic carotid cavernous sinus fistula following a gunshot wound to the face.J Emerg Med 1997;15:23-9.

2. Mostafa G, Sing RF, Matthews BD, Heniford BT. Traumatic carotid cavernous fistula. J Am Coll Surg 2002;194:841. CrossRef

3. Vasconcelos BC, Porto GG, Carneiro SC. Post-trauma exophthal- mos caused by a carotid-cavernous fistula. Braz J Otorhinolaryngol 2009;75:767. CrossRef

4. Aissa A, Arous A, Alouini R, Taktak J, Allani M. Ballistic trauma resulting in carotid-cavernous fistula. [Article in French] J Fr Ophtalmol 2012;35:722.e1-4. [Abstract] CrossRef

5. Kurata A, Takano M, Tokiwa K, Miyasaka Y, Yada K, Kan S. Spontaneous carotid cavernous fistula presenting only with cranial nerve palsies. AJNR Am J Neuroradiol 1993;14:1097-101.

6. Lewis AI, Tomsick TA, Tew JM Jr. Management of 100 consecutive direct carotid-cavernous fistulas: results of treatment with detachable balloons. Neurosurgery 1995;36:239-45. CrossRef

7. Ringer AJ, Salud L, Tomsick TA. Carotid cavernous fistulas: anatomy, classification, and treatment. Neurosurg Clin N Am 2005;16:279-95.

8. Barrow DL, Spector RH, Braun IF, Landman JA, Tindall SC, Tindall GT. Classification and treatment of spontaneous carotid-cavernous sinus fistulas. J Neurosurg 1985;62:248-56. CrossRef

9. Jacobson BE, Nesbit GM, Ahuja A, Barnwell SL. Traumatic indirect carotid-cavernous fistula: report of two cases. Neurosurgery 1996;39:1235-8. CrossRef

10. Debrun GM, Viñuela F, Fox AJ, Davis KR, Ahn HS. Indications for treatment and classification of 132 carotid-cavernous fistulas. Neurosurgery 1988;22:285-9. CrossRef

11. Argo A, Bono G, Zerbo S, Triolo V, Liotta R, Procaccianti P. Post-traumatic lethal carotid-cavernous fistula.J Forensic Leg Med 2008;15:266-8.

12. Chen YW, Jeng JS, Liu HM, Hwang BS, Lin WH, Yip PK. Carotid and transcranial color-coded duplex sonography in different types of carotidcavernous fistula. Stroke 2000;31:701-6. CrossRef

13. Ouanounou S, Tomsick TA, Heitsman C, Holland CK. Cavernous sinus and inferior petrosal sinus flow signal on three-dimensional time-offlight MR angiography. AJNR Am J Neuroradiol 1999;20:1476-81.

14. Eggenberger E, Lee AG, Forget TR Jr, Rosenwasser R. A bruital headache and double vision. Surv Ophthalmol 2000;45:147-53. CrossRef

15. Lu X, Hussain M, Ni L, Huang Q, Zhou F, Gu Z, et al. A comparison of different transarterial embolization techniques for direct carotid cavernous fistulas: a single center experience in 32 patients. J Vasc Interv Neurol 2014;7:35-47.

16. Kupersmith MJ, Berenstein A, Choi IS, Warren F, Flamm E. Management of nontraumatic vascular shunts involving the cavernous sinus. Ophthalmology 1988;95:121-30. CrossRef

17. Wang W, Li YD, Li MH, Tan HQ, Gu BX, Wang J, et al. Endovascular treatment of post-traumatic direct carotid-cavernous fistulas: A singlecenter experience. J Clin Neurosci 2011;18:24-8. CrossRef

18. Zhang Z, Wang C, Yang K, Tang J, Zhang C, Xie X, et al. Endovascular embolization of refractory traumatic carotid cavernous fistula with micro-coils: a preliminary experience. Turk Neurosurg 2014;24:190-5.

19. Gemmete JJ, Chaudhary N, Pandey A, Ansari S. Treatment of carotid cavernous fistulas. Curr Treat Options Neurol 2010;12:43-53. CrossRef

\section{OLGU SUNUMU - ÖZET}

Yüz bölgesine ateşli silah yaralanması sonrası görme kaybı ile başvuran ve endovasküler tedavi sonrası semptomları düzelen gecikmiş karotikokavernöz fistül olgusu

\section{Dr. Fatih Alagöz,, ${ }^{1}$ Dr. Fevzi Yılmaz, ${ }^{2}$ Dr. Bedriye Müge Sönmez, ${ }^{2}$ Dr. Ali Erdem Yıldırım, ${ }^{1}$ Dr. Muhammed Evvah Karakılıç${ }^{2}$}

${ }^{1}$ Ankara Numune Eğitim ve Araştırma Hastanesi, Beyin Cerrahisi Kliniği, Ankara

${ }^{2}$ Ankara Numune Eğitim ve Araştırma Hastanesi, Acil Tıp Kliniği, Ankara

Karotit kavernöz fistüller karotis arter ve kavernöz sinüs arasındaki anormal bağlantılardır. Künt ve penetran kafa yaralanmaları karotikokavernöz fistül ile sonuçlanabilir. Her ne kadar nadir olarak ortaya çıksa da tanısı acil serviste konabilir. Bu yazıda, 35 gün önce yüzüne ateşli silah yaralanmasından sonra sağ gözünde kızarıklık, ağrı, görmede bulanıkık, görme kaybı ve yüzün üst yarısında şişme şikayeti ile acil servise başvuran 26 yaşındaki hasta sunuldu.

Anahtar sözcükler: Ateşli silah yaralanması; endovasküler girişim; endovasküler tedavi; karotid kavernöz fistül.

Ulus Travma Acil Cerrahi Derg 2016;22(2):199-20I doi: 10.5505/tjtes.20I5.18234 